8-15-2011

\title{
Failure of the Current Anti-Corruption Strategy in Afghanistan
}

Hugh Barrett McClean

University of Baltimore School of Law, hmcclean@ubalt.edu

Follow this and additional works at: http://scholarworks.law.ubalt.edu/all_fac

Part of the Comparative and Foreign Law Commons, and the International Law Commons

\section{Recommended Citation}

Failure of the Current Anti-Corruption Strategy in Afghanistan, 9 J. Contract Mgmt. 41 (2011)

This Article is brought to you for free and open access by the Faculty Scholarship at ScholarWorks@University of Baltimore School of Law. It has been accepted for inclusion in All Faculty Scholarship by an authorized administrator of ScholarWorks@University of Baltimore School of Law. For more information, please contact snolan@ubalt.edu. 
University of Baltimore School of Law Legal Studies Research Paper Series

\section{FAILURE OF THE CURRENT ANTI-CORRUPTION STRATEGY IN AFGHANISTAN}

An examination of emerging international anticorruption efforts and their role in combating corruption from the lowest to highest levels of Afghan society.

By Hugh B. McClean,

University of Baltimore School of Law

August 15, 2011

Accepted Paper

9 J. CONTRACT MGMt. 41 (2011)

\section{Table of Contents}

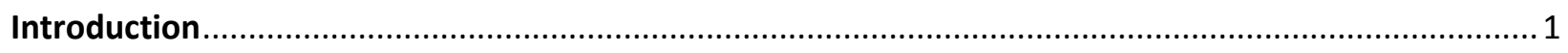

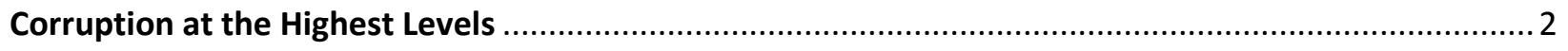

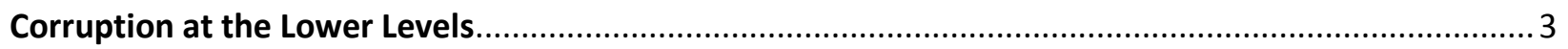

Strengthening Key Institutions: The Current Strategy .............................................................. 4

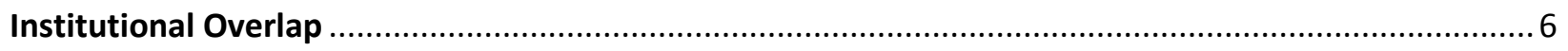

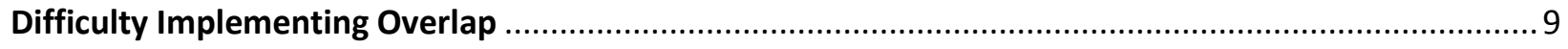

Tailoring the Strategy: Implementation Failures in South-Central Asia............................................. 11

Principal-Agent Model: A Framework for Analyzing Failed Prosecutions........................................... 12

Collective Action Theory: A Framework for Analyzing Institutional Overlap Failures .........................15

A Country at War

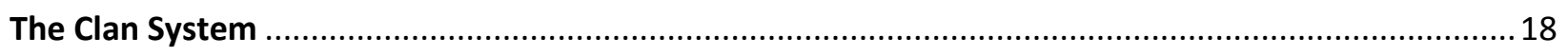

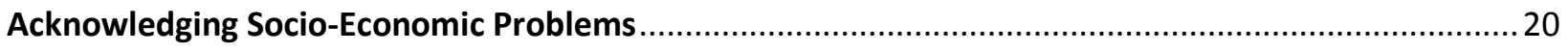

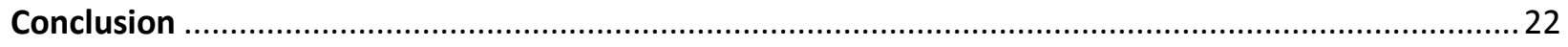




\section{Introduction}

Agents of the Major Crimes Task Force and the Sensitive Investigative Unit, two newly formed Afghanistan anti-corruption task force teams ${ }^{1}$, moved swiftly under cover of darkness during an early morning raid in Kabul in July $2010 .^{2}$ They carefully positioned themselves around the home of Mohammed Zia Salehi, their target. The teams had been monitoring Mr. Salehi, head of administration for President Hamid Karzai's National Security Council, for some time and were now moving to make the arrest. ${ }^{3}$ During the surveillance leading up to the arrest, the units had obtained a recording of Mr. Salehi allegedly soliciting a bribe from a money transfer company called New Ansari. Mr. Salehi had allegedly offered to intervene in a corruption investigation against New Ansari. ${ }^{4}$ The arrest would be a true test of the units' ability to curb corruption, and its successful execution would be a positive reflection on the U.S. Federal Bureau of Investigation, who mostly trained the teams.

The units found Mr. Salehi at his home and made the arrest without incident. Strangely, Mr. Salehi then called President Hamid Karzai, apparently surprised that the anti-corruption teams had carried through with plans to arrest him. ${ }^{5}$ Shortly thereafter, President Karzai released Mr. Salehi from prison and dismissed all charges against him. President Karzai claimed the heavy-handed way in which the arrest was carried out, including an early morning arrest in which Mr. Salehi was placed in foot restraints and hand-cuffs, violated international

\footnotetext{
${ }^{1}$ Rod Nordland, Afghan Government Drops Corruption Charges Against Aide, N.Y. Times, Nov. 8, 2010 , at A8.

${ }^{2}$ See Eric Schmitt, Karzai Admits Helping Free Aide Accused of Graft, N.Y. Times, Aug. 23, 2010, at A8.

${ }^{3}$ Rod Nordland \& Alissa J. Rubin, New Afghan Corruption Inquiries Frozen, N.Y. Times, Sept. 14, 2010, http://www.nytimes.com/2010/09/15/world/asia/15afghan.html?sq=new afghan corruption inquiries frozen\&st=cse\&scp=1\&pagewanted=all.

${ }^{4}$ Rod Nordland, supra note 1; New Ansari is believed to be a money laundering business that sends billions of dollars to Afghan politicians, insurgents and drug smugglers.

${ }^{5}$ See Nordland \& Alissa, supra note 3.
} 
humanitarian law. ${ }^{6}$ President Karzai has since issued a decree limiting the power of the two anticorruption units, but details as to how the decree will be implemented have not been released. ${ }^{7}$

\section{Corruption at the Highest Levels}

The frustrating situation described above highlights the problems associated with combating corruption in Afghanistan. Unfortunately, the events described in Mr. Salehi's case are not unique. Corruption has come to the forefront as the U.S. tries to balance efforts to back anti-corruption teams in Afghanistan while maintaining a positive relationship with the Karzai government. This balancing act has become quite difficult given President Karzai's lackadaisical attitude about corruption, evidenced when he openly admitted that he accepts "bags of cash" from countries such as Iran for unspecified projects. ${ }^{8}$

The presidential pardon of one of President Karzai's top advisors is even more disturbing given the number of pending investigations involving other high-ranking officials. In an interview with the New York Times, Mr. Fazel Ahmed Faqiryar, the former deputy attorney general for President Karzai, said there were a number of cases that were being blocked by President Karzai and his current Attorney General, Ishaq Aloko. ${ }^{9}$ Investigations into cabinet ministers, as well as ambassadors and provincial governors, have all been halted. Of the 25 current and former Afghan officials under investigation by the two anti-corruption task forces, only three have been charged. The implication is that the U.S. backed anti-corruption teams and

\footnotetext{
${ }^{6} I d$. Other witnesses to the arrest said Mr. Salehi had been asked to turn himself in but failed to do so.

${ }^{7}$ Mark Mazzetti \& Rod Nordland, U.S. Debates Karzai's Place in Graft Fight, N.Y. Times, Sept. 15, 2010, at A1.

${ }^{8}$ PBS News Hour: Bags of Cash: Are Iran, Karzai Playing All Sides? (PBS television broadcast Oct. 26, 2010) (transcript available at http://www.pbs.org/newshour/bb/asia/july-dec10/afghan2_10-26.html).

${ }^{9}$ Dexter Filkins \& Alissa J. Rubin, Graft-Fighting Prosecutor Fired in Afghanistan, N.Y. Times, Aug. 28, 2010, at A1.
} 
the Karzai government are not seeing eye-to-eye. Currently, 17 members of Karzai's cabinet, 5 provincial governors, and 3 ambassadors are under investigation. In only three cases has an Afghan official been charged, with no verdicts yet rendered. ${ }^{10}$ Before taking any action on the cases, the Karzai administration said they would wait for new regulations governing the task forces to be released by the Afghanistan Judiciary Ministry. ${ }^{11}$

\section{Corruption at the Lower Levels}

Corruption in Afghanistan is not limited to high-ranking officials who have the leverage to demand bribes, though they are at the top of what can be considered a hierarchy of corruption. ${ }^{12}$ A recent study by Transparency International ranked Afghanistan 172 out of 180 in its 2008 global corruption index, suggesting that bribes are systemic and exist at all levels of society. ${ }^{13}$ The United Nations Office on Drugs and Crime (UNODC) conducted a study using findings as reported by the victims of bribery in Afghanistan. The study found that judges, prosecutors, custom officers, police officers, municipal and provisional officials receive an estimated $\$ 200$ to $\$ 1000$ in bribes. Doctors, nurses, and teachers rank lower in the hierarchy, receiving bribes under $\$ 100 .{ }^{14}$ Victims reported that $78 \%$ of the time bribes are used to speed up processes, and at other times to receive "better treatment." Half of all Afghans reported paying bribes, averaging $\$ 158$ a person. Women reported paying bribes more often than men (53\% compared to 39\%), and reported paying more bribes in health and education sectors. In 2009,

\footnotetext{
${ }^{10}$ See id.

${ }^{11}$ See id.

${ }^{12}$ See, e.g., Wayne Kondro, Afghanistan's Cancer of Corruption, 182 CANADIAN MED. Ass'N J., Mar. 9, 2010, at 209.

${ }^{13}$ Nita Colaco, Crooked Progress: Afghanistan Tackles Corruption, HARV. InT'L REV., Fall 2008, at 12, 13.

${ }^{14}$ U.N. Office on Drugs and Crime, Statistics and Surveys Section, Corruption in Afghanistan: Bribery as Reported by the Victims, Jan. 2010 (Enrico Bisogno, Anna Alvazzi del Frate, Philip Davis).
} 
Afghans paid out more than $\$ 2.5$ billion in bribes, almost one-quarter (23\%) of the country’s gross domestic product (GDP). Perhaps not surprisingly, "public dishonesty" was reported as a grave concern, more so than security or unemployment. ${ }^{15}$

Bribery also varies by geographic region. The northern and southern areas of Afghanistan have the highest reported occurrences of bribery $(62 \%$ in the north and $61 \%$ in the south), while the east-central and western regions reported somewhat less bribery (53\% in eastcentral regions and $21 \%$ in the west). Rural areas are hit harder than towns, and have higher reported bribes (56\% in rural areas as compared to $46 \%$ in towns). ${ }^{16}$

Two notable ironies further reveal the extent of the bribery problem. First, some bribery victims suggested that the bribe system was beneficial to citizens and government officials, and stated that bribes helped them avoid fines and enabled them to receive better treatment. Second, $54 \%$ of citizens reportedly believed international organizations and other non-governmental organizations are corrupt and are only in Afghanistan to get rich. ${ }^{17}$ These ironies, as well as the other statistics reported by the UNODC, reflect the extent to which corruption pervades the lives and minds of those living in Afghanistan.

\section{Strengthening Key Institutions: The Current Strategy}

In helping to develop strong anti-corruption task forces to combat the problem within Afghanistan, the United States has aligned itself with current nation-building strategies. In the last decade, a number of international organizations, including the World Bank, the International

\footnotetext{
${ }^{15} I d$. at 4.

${ }^{16} I d$. at 9 .

${ }^{17} I d$. at 10.
} 
Monetary Fund (IMF), the United Nations Development Programme (UNDP), Transparency International, and Global Integrity have taken a much broader view of anti-corruption than they have previously held. ${ }^{18}$ Where they once viewed their mission as assuring the integrity of their own organizations' projects, they now see their role as supporting more fundamental structural reforms. ${ }^{19}$ Relying on both governmental and non-governmental aid, strategies today are aimed at organizing and planning well-coordinated and directed anti-corruption efforts across a spectrum of institutions within a country.

For example, the international organization Transparency International has focused on four key nation-building components for post-conflict countries: (1) security and public safety, (2) political leadership, (3) economic development, and (4) social integration. ${ }^{20}$ A number of recommended actions targeted to achieve anti-corruption goals within those areas can be employed. Within security and public safety, for example, the corruption risk is bribery of police and military officials, as well as abuse of power and influence of judges. Therefore, target actions include implementing competitive and adequate public wages, whistleblower hotlines for staff and citizens, internal oversight mechanisms, and asset declarations. ${ }^{21}$ Within the political leadership sector, the risk is corruption in civil servant positions. The goal in this sector is to build institutions similar to the Government Accountability Office in the United States or the Audit Commission in Great Britain, which provide an array of monitoring and bonding mechanisms for the government. ${ }^{22}$ Therefore, target actions include transparency of political

\footnotetext{
${ }^{18}$ See, e.g., SUSAN ROSE-ACKERMAN, CORRUPTION AND GOVERNMENT: CAUSES, CONSEQUENCES AND REFORM 182 (CAMBRIDGE UNIVERSITY PRESS, 1999).

${ }^{19}$ See id. at 182.

${ }^{20}$ Alfred Bridi \& Craig Fagan, After the Conflict: Nation-Building and Corruption 6-7 (Transparency Int'l, Working Paper No. 04, 2010).

${ }^{21}$ See id. at 6.

${ }^{22}$ See Rose-Ackerman, supra note 18, at 163 . "Bonding" is a term used in anti-corruption parlance referring to mostly contractual anti-corruption mechanisms requiring self-monitoring by the employee.
} 
party financing, judiciary reforms, public expenditure tracking, parliamentarian oversight, and sanctioning of high-level nominations. ${ }^{23}$

Rule of law institutions are also considered highly strategic because of their deterrent effect. ${ }^{24}$ Focusing resources on the military, police, and judiciary can bring about relatively quick and visible change, thus increasing the public's respect for rule of law. ${ }^{25}$ Target actions in this area seek to increase public knowledge about judicial systems and decrease opportunities for corrupt practices by making the judicial system more transparent. ${ }^{26}$ Annual reports are a means to disclose judicial decisions and their reasoning, and make budgetary and conflict of interest information easily available to the public. ${ }^{27}$ Additional measures aimed at prosecutors, including publicly accessible prosecution guidelines, public proceedings, and public reports explaining prosecutorial decisions, provide accountability to strengthen the rule of law. ${ }^{28}$

The cooperation of each institution is necessary to achieve the goal of making corruption a high-risk low-return activity. ${ }^{29}$ The approach is a holistic one, and the stability of one institution will do little to combat corruption without the interconnectedness of the others. ${ }^{30}$ As we have seen in the case of the nascent Afghan anti-corruption task forces, the strength of one organization acting alone simply is not enough.

\section{Institutional Overlap}

${ }^{23} I d$.

${ }^{24}$ See Jeremy Pope, Enhancing Accountability and Ethics in the Public Sector, in CURBING CORRUPTION: TOWARD A MODEL FOR BuILDING NATIONAL INTEGRITY 105, 110-11 (Rick Stapenhurst \& Sahr J. Kpundeh eds., The World Bank, 1999).

${ }^{25}$ See id. at 108.

${ }^{26}$ See Transparency Int'1, Enhancing Judicial Transparency, Policy Paper No. 07/2007 (2007).

${ }^{27}$ Id. at 3.

${ }^{28}$ See id. at 2.

${ }^{29}$ See Pope, supra note 24, at 111.

${ }^{30}$ See id. 
The task of reducing corruption falls on multiple institutions. Not only must these institutions be connected, but they must overlap and integrate their individual strengths and strategies. Anti-corruption efforts have often failed where the weaknesses of some institutions have blocked the progress of others. This is particularly apparent in systems with an overreliance on legal remedies, without strong leadership, or that favor prosecutions of low-level actors rather than high-level officials. ${ }^{31}$

An effective anti-corruption policy will holistically rely upon multiple institutions, often overlapping with foreign partners outside the government, so that multiple solutions are available for a particular corruption problem. The extensive overlapping of institutions in the 2008 prosecution of Siemens Aktiengesellschaft (Siemens) is one example. ${ }^{32}$ Siemens and three of its subsidiaries, Siemens S.A. - Argentina (Siemens Argentina), Siemens Bangladesh Limited (Siemens Bangladesh) and Siemens S.A. - Venezuela (Siemens Venezuela), were accused of bribery and bookkeeping violations under the U.S. Foreign Corrupt Practices Act (FCPA). The broad aim of the FCPA is to criminalize acts influencing the business decision-making of foreign officials. ${ }^{33}$ Siemens was accused of violating the internal controls and books and records provisions under the FCPA, while its two non-European subsidiaries, Siemens Bangladesh and Siemens Venezuela, pleaded guilty to bribery. ${ }^{34}$ Siemens had acknowledged using removable Post-It notes to record approval for illegal payments, falsifying accounting records, creating fictitious invoice payments to consultants who performed no services, and using "off-book"

\footnotetext{
${ }^{31}$ See Jeremy Pope, Elements of a Successful Anticorruption Strategy, in CURBING CORRUPTION: TOWARD A MODEL FOR BUILDING NATIONAL INTEGRITY 97, 98 (Rick Stapenhurst \& Sahr J. Kpundeh eds., The World Bank, 1999).

${ }^{32}$ Peter B. Clark \& Jennifer A. Suprenant, Siemens-Potential Interplay of FCPA Charges and Mandatory Debarment under the Public Procurement Directive of the European Union, April 2009, http://www.cadwalader.com/assets/article/030409ABASiemensPotentialInterplay.pdf.

${ }^{33}$ See Jessica Tillipman, Foreign Corrupt Practices Act Fundamentals, Briefing Papers No. 08-10 (Sept. 2008).

${ }^{34}$ See Clark \& Suprenant, supra note 32, at B-73.
} 
accounts for illegal payments. ${ }^{35}$ The subsidiaries had made payments to foreign contract officials, upwards of over $\$ 18.7$ million in one case, to guarantee that the subsidiaries would obtain and retain contracts for certain projects. ${ }^{36}$

The U.S. Department of Justice (DOJ) and the U.S. Securities and Exchange Commission (SEC) were able to use the two main components of the FCPA, the bribery provision and the bookkeeping provision, to extract $\$ 800$ million ( $\$ 450$ million to the DOJ and $\$ 350$ million to the SEC) from Siemens. ${ }^{37}$ By charging only the Bangladesh and Venezuela subsidiaries with bribery, and not the European subsidiaries, the DOJ allowed Siemens (the parent-company) to avoid suspension and debarment under the Public Procurement Directive of the European Union (EU). ${ }^{38}$ The structuring of the plea-agreement by the DOJ and the SEC was likely purposeful, as suspension and debarment is viewed as an extremely harsh penalty, reserved only for the most egregious cases, which this apparently was not. ${ }^{39}$ Even without debarring the parent-company, the penalties were severe, as the fines and disgorgement in the United States were in addition to those imposed the Munich Public Prosecutor's Office. The Siemens case was the first simultaneous resolution of criminal and civil transnational bribery charges by the United States and a foreign government. ${ }^{40}$

One of the most striking features about the case is its jurisdictional reach. The DOJ and SEC were able to coordinate an international investigation which resulted in a foreign company being charged, prosecuted, and sanctioned for engaging in corrupt business practices overseas.

\footnotetext{
${ }^{35} \mathrm{Id}$. at $\mathrm{B}-72$.

${ }^{36} \mathrm{Id}$. at $\mathrm{B}-73$.

${ }^{37} \mathrm{Id}$. at B-71.

${ }^{38}$ Directive 2004/18/EC of the European Parliament and of the Council of 31 March 2004 on the coordination of procedures for the award of public works contracts, public supply contracts and public service contracts, 2004 O.J. (L 134), 114-240; The Directive imposes mandatory suspension and debarment for bribery convictions.

${ }^{39}$ See Clark \& Suprenant, supra note 32, at B-71.

${ }^{40} \mathrm{Id}$.
} 
While the reach of the FCPA is quite broad, the results achieved by these agencies simply wouldn't be possible without the interconnectivity of strong anti-corruption institutions inherent in the U.S. justice system. While the United States and other modern countries might view this overlap as convenient, leading anti-corruption scholars and organizations have touted it as the cornerstone for a robust anti-corruption system. The Siemens case goes even one step further, demonstrating overlap between the DOJ and the Munich Prosecutor's Office. Taking into consideration both U.S. and EU law, the United States and Germany offered plea agreements which exacted a very specific and calculated outcome, one which Siemens ultimately accepted. It is not so difficult to imagine a very different chain of events if the institutions were not so well overlapped, and thus could not support the unique jurisdictional boundaries of this case.

\section{Difficulty Implementing Overlap}

Unfortunately, implementing a strategy that requires the overlapping of established institutions has many hurdles. The international oversight group Global Integrity has focused on some of these hurdles in their 2008 report on anti-corruption efforts in Iraq. ${ }^{41}$ Iraq received a very weak rating (53 of 100 listed countries) which was attributed to weak institutional governance mechanisms and a lack of capacity to enforce those mechanisms. ${ }^{42}$ While the country has laws in place, it does not have the institutions to support them. For instance, with respect to Iraq's procurement process, the report found that there are indeed strong procurement integrity policies that were codified by the Coalition Provisional Authority (CPA) and adopted by the subsequent Iraqi Government. In fact, the Iraq procurement system has rules implementing

\footnotetext{
${ }^{41}$ See Global Integrity, Global Integrity Report: Iraq 2008, http://report.globalintegrity.org/Iraq/2008.

${ }^{42}$ See id.
} 
mandatory government professional training, competitive bidding, sole sourcing, and debarment. ${ }^{43}$ However, these rules are weakened by that fact that there are no laws addressing conflicts of interest for public procurement officials, ${ }^{44}$ redresses for unsuccessful bidders to challenge procurement decisions, or challenges to an official review of a procurement decision. ${ }^{45}$ More importantly, in practice, many of the regulations are not enforced.

The Obama administration's success in helping to establish the Afghan Major Crimes Task Force and the Sensitive Investigative Unit is commendable. Further, it is aligned with the recommendations of leading non-profit agencies monitoring corruption in various nations as discussed above. The challenge, of course, is that the strength of one institution is not realized if it is not backed by a network of equally strong interconnected institutions. Unfortunately, the Obama administration is facing the same problem encountered by many under-developed nations. That is, if corruption is fought not with one but with many interconnected institutions, how does one go about establishing such a network of well-funded and ethically-minded institutions in places without the necessary resources to build them? President Karzai claimed there were too many humanitarian injustices during the arrest of Mr. Salehi to warrant charging him, ${ }^{46}$ and the Deputy Attorney General of Afghanistan, Mr. Rahmatullah Nazari, stated that because wiretap evidence can only be used in drug cases, Mr. Salehi's case could not be prosecuted. ${ }^{47}$ In the end, the difficulty for the two anti-corruption units is not that they are conducting an investigation in a war zone. The challenge, instead, is working with a nontransparent prosecutorial system and the inconsistencies found in Afghanistan's rule of law. As

\footnotetext{
${ }^{43}$ See id.

${ }^{44}$ Law no. 87, created by the CPA, provides public procurement guidelines, and establishes the Ministry of Planning and Development Cooperation as the overseeing agency for implementing procurement guidelines. However, the law was not adopted by the Iraqi government. See id.

${ }^{45}$ See Global Integrity, supra note 41.

${ }^{46}$ See Nordland \& Rubin, supra note 3.

${ }^{47}$ See Nordland, supra note 1.
} 
one Afghan businessman close to President Karzai said, "The fact that the guy got away means it's a toothless tiger." 48

\section{Tailoring the Strategy: Implementation Failures in South-Central Asia}

The concept of creating strong overlapping institutions has been endorsed by many international anti-corruption organizations during the last decade. ${ }^{49}$ However, a number of scholars have since questioned this approach, observing increased corruption in countries where the approach has been implemented. One recent study showed an increase in corruption in Africa since implementation of the approach in $1998{ }^{50}$ Data from organizations tracking corruption seems to support this observation. A review of Transparency International's Corruption Perceptions Index (CPI) results for 2010 suggests that south-central Asia has made little progress, if any, with this strategy. On the CPI scale, which ranges from " 0 " to " 10 ", Afghanistan (1.4) and Iraq (1.5) rank significantly lower than other countries in the region. ${ }^{51}$ Moreover, the number of countries in south-central Asia and Africa receiving "highly corrupt" rankings compared to neighboring countries receiving significantly better scores, such as the United Arab Emirates (6.3), Oman (5.3), Qatar (7.7), and Saudi Arabia (4.7), is significant. To the northwest are countries with mostly high scores, including Austria (7.9), Poland (5.3),

\footnotetext{
${ }^{48}$ See Nordland \& Rubin, supra note 3.

${ }^{49}$ See, e.g., Petter Langseth, Rick Stapenhurst, \& Jeremy Pope, National Integrity Systems, in CURBING CORRUPTION: TOWARD A MODEL FOR BUILDING NATIONAL INTEGRITY 127, 127-50 (Rick Stapenhurst \& Sahr J. Kpundeh eds., The World Bank, 1999).

${ }^{50}$ See Anna Persson, Bo Rothstein, \& Jan Teorell, The failure of Anti-Corruption Policies: A theoretical Mischaracterization of the Problem (The Quality of Government Institute, QoG Working Paper Series 2010:19, 2010).

51 Transparency Int'1, Corruption Perceptions Index 2010 (October, 2010).
} 
Germany (7.9), Norway (8.6), Sweden (9.2) and Finland (9.2). The Unites States (7.1), Canada (8.9), Chile (7.2), and Uruguay (6.9) rank among the highest in the western-hemisphere. ${ }^{52}$

The 2010 CPI results seem to confirm that the current strategy is stalling in certain countries. There could be a number of reasons for this, including political, historical, cultural, or other socio-economic factors. What seems clear is that the strategy is not a "one size fits all" solution, and must be applied only after it is carefully tailored to meet the needs of the particular country's conditions..$^{53}$

\section{Principal-Agent Model: A Framework for Analyzing Failed Prosecutions}

One theoretical model which may help to explain the failure of the Obama administration's efforts to carefully tailor a strategy to assist in the prosecution of alleged corrupt officials in Karzai's cabinet is the principal-agent model. The model has become a very useful framework to apply economic and social science principals to almost any organization, including business, secondary education, government bureaucracies, unions, and a number of other markets. ${ }^{54}$ Innovative scholars have recently started to rely on the principal-agent model to develop an overarching framework to examine corruption in government procurement systems from a legal and socio-economic perspective. ${ }^{55}$

The model describes corruption in terms of classic agency theory principles. An agent is employed to act on behalf of the principal. However, the agent will always exert, to some

\footnotetext{
${ }^{52} I d$.

${ }^{53}$ See Rose-Ackerman, supra note 18, at 197.

${ }^{54}$ See Michael C. Jenson \& William H. Meckling, Theory of the Firm: Managerial Behavior, Agency Costs and Ownership Structure, 3 J. FIN. ECON. 305 (1976), intending broad applicability of the principal-agent model. ${ }^{55}$ See Chris Yukins, A Versatile Prism: Assessing Procurement Law Through The Principal-Agent Model (forthcoming 2011).
} 
degree, his or her own interests, and therefore can never be completely loyal to the principal. ${ }^{56}$ The agent's interests could be as innocent as a departure from their employment for personal reasons, such as leaving work early, or something recognizably malum in se, such as taking a bribe. Innocent or not, the agent will, to some degree, betray the principal's interests for the sake of their own. Further, because the agent is in the position to be more knowledgeable about the principal's dealings for which the agent oversees, the agent is in a position to take advantage of the principal. Ultimately, when the agent is more likely to benefit by diverging from the principal than remaining faithful, the agent will act corruptly. ${ }^{57}$ Thus, there is inherent tension in the principal-agent relationship. The principal, on the other hand, is focused on incentivizing the agent to act as least corrupt as possible through methods such as monitoring and bonding. ${ }^{58}$ Monitoring is essentially oversight on behalf of the principal which attempts to limit or eliminate the agent's diversions from the principal's objectives. Bonding involves the use of contractual self-constraints designed to reduce diversions, but is really only effective if the agents are able to monitor themselves. ${ }^{59}$ In the procurement realm, bonding is made more effective through the forfeitures of money ("sanctions") or freedom (criminal "punishment") if the agent strays from the principal's objectives. ${ }^{60}$

When applying the principal-agent model to government bureaucracies, the principal is typically viewed as the government, and the agent a governmental bureaucrat. However, the

\footnotetext{
${ }^{56}$ See, e.g., Kathleen M. Eisenhardt, Agency Theory: An Assessment and Review, 14 ACAD. MGMT. REV. 57, 57-70 (1989).

${ }^{57}$ See Robert E. KLITGAARD, CONTROLLING CORRUPTION 21-27 (1988).

${ }^{58} \mathrm{See}$ id. at 24-25; Klitgaard argues that because the cost of completely eradicating corruption is so high, the incentives should be aimed at an "optimal level of corrupt behavior" rather than zero corruption.

${ }^{59}$ See Sharon Hannes, Reverse Monitoring: On the Hidden Role of Employee Stock-Based Compensation $105 \mathrm{MiCH}$. L. REV. 1421, 1438-39 (2007).

${ }^{60}$ See Yukins, supra note 55.
} 
public-at-large could be viewed as the principal, and the government the agent of the people. ${ }^{61} \mathrm{~A}$ number of actors can be contemplated for the roles, but the consistent underlying assumption of the model, almost uniformly, is that some actors seek to avoid corruption. It assumes that there are a number of members in society willing to act as principals to hold their public officials accountable. ${ }^{62}$ As we have seen in the cases involving the prosecution (though not the investigation) of high-level Afghan officials, that concept may not be true. In Afghanistan, the new corruption task forces are emerging as a very effective monitoring tool. They have done an excellent job building cases against top-level cabinet officials who, in that situation, are the diverging agents. However, the principal, President Karzai, is unconcerned with monitoring his agents. In fact, he has been angered by the actions of his monitors and has alleged "humanitarian violations" by the investigative units. ${ }^{63}$ The immediate release of Mr. Salehi from prison and dismissal of all his charges can only be seen as an abandonment of President Karzai's role as principal.

The principal-agent model can be applied in a somewhat different fashion when analyzing these failed prosecutions. Rather than providing insights into the relationship between the principal and agent, the model instead identifies an issue that may be shared by other countries failing to implement institutional overlap. That is, traditional correcting mechanisms of monitoring and bonding provided by strong overlapping institutions will not reduce corruption when principals abandon their monitoring roles. While the Obama administration may believe President Karzai is the least harmful leader for Afghanistan at the moment, the shortcomings of a

\footnotetext{
${ }^{61}$ It is a useful exercise to think about who is the principal when applying this model. For example, the model offers a very different perspective if the United States is the principal, and President Karzai the agent.

62 See Persson, Rothstein, \& Teorell, supra note 50, at 10.

${ }^{63}$ Rod Nordland and Alissa J. Rubin, supra note 3.
} 
leader lacking uncompromising integrity are becoming more problematic. In the absence of monitoring and bonding by the principal, corruption has flourished.

\section{Collective Action Theory: A Framework for Analyzing Institutional Overlap Failures}

The principal-agent model suggests one reason why corruption at the highest levels has not been reduced, and why the prosecutions of a number of high-level officials in the Karzai administration have stalled. But this does not fully explain the indifferent reaction by Afghan society at-large. Why aren't the Afghan people crying out when they see the pardoning of so many corrupt officials? Is the bribe-paying half of Afghan society really content with such a system? Certain unique characteristics have perhaps paved the way for corruption in Afghanistan, so much so that corruption has become the status quo.

The pervasiveness of corruption that has enveloped Afghan society at-large is the exact issue raised by recent scholars applying collective action theory to post-conflict nations. ${ }^{64}$ Collective action theory begins with the assumption that all actors in a pervasively corrupt society act for their own self-interests. The theory suggests that, both at the highest and lowest levels of society, there is an overwhelming absence of "principled principals." 65 The reason for this absence is because a principal's course of action is greatly influenced by how he or she perceives others in society will act, regardless of normative beliefs. ${ }^{66}$ One study found that even though people in Africa recognized bribes as morally and perhaps legally wrong, they tolerated

\footnotetext{
${ }^{64}$ See Persson, Rothstein, \& Teorell, supra note 50, at 12.

${ }^{65} \mathrm{Id}$.

${ }^{66}$ See Elinor Ostrom, A Behavioral Approach to the Rational Choice Theory of Collective Action: Presidential Address, American Political Science Association, 1997, 92 THE AM. POL. SCI. REV., 1, 2 (1998).
} 
them because they believed it was the predominant means of doing business. ${ }^{67}$ Unlike the principal-agent model, in which principals seek to incentivize agents to act in accordance with their will, collective action theory suggests principals won't bother to correct their agents if they perceive most of society as corrupt. Such actors will always view the short-term benefits of engaging in corruption as outweighing the costs.

The collective action problem helps to explain why, in certain corrupt societies, the building-up of key institutions has not been as effective as proponents had hoped. Afghanistan in particular has had a tumultuous history, and the patron-client relationships that have dominated the society in the absence of a strong central government lend credence to the idea that Afghanistan does indeed suffer from a collective action problem. However, before giving any great weight to the notion that collective action acts as a barrier to many of the institutionalstrengthening approaches endorsed by the United States and the international community, a historical overview is helpful in determining to what extent, if at all, this problem exists in Afghan society.

\section{A Country at War}

Afghanistan has a long history of defending itself from occupiers. To veterans of those wars, the nationalities of the invaders have become blurred over time. A retired Mujahideen commander was once asked about the current occupation of troops in Afghanistan, and used the term "Americans" to refer to all foreign troops in the area. The reporter interviewing him had recently been imbedded with the Americans and knew the troops in that particular area were not

\footnotetext{
${ }^{67}$ See Persson, Rothstein, \& Teorell, supra note 50, at 13.
} 
Americans. The commander retorted, "We see their vehicles driving around and we don't know who they are. We just know they are foreign."68

The blurring of foreign occupiers is due not only Afghanistan's constant regime changes, but also because of its role as a "buffer" state for super-powers battling for dominance in central Asia. Known as The Great Game ${ }^{69}$ the British and the Russians competed for dominance, using Afghanistan as a battle ground, as early as $1813 .{ }^{70}$ Interest in the region was prompted by Britain's fear that British India would be vulnerable to the Russia Empire if the Russians were able to use Afghanistan as a staging area to attack India. When the British saw the Russians increasingly replacing Afghan khanates, ${ }^{71}$ they launched the First Anglo-Afghan War in the early $19^{\text {th }}$ century. Resiliently, the Afghans fought to keep their land from the British in a series of three Anglo-Afghan wars lasting until the Afghan-Indian border was finally settled and the British left Afghanistan in 1919.

Between the defeat of the British in the Third Afghan-Anglo War and the Soviet invasion of Afghanistan in 1979, Afghanistan again played the buffer state role, this time between the United States and the Soviet Union. Beginning in the 1950's and lasting until the 1980's, Afghanistan received an increasing amount of aid from the Soviets, and became one of four countries to receive the majority of Soviet aid during that time. ${ }^{72}$ Afghanistan's King Zahir Shah and his prime minister, Daun Kahn, thought that Afghanistan could benefit from the animosity between the East and West, and began receiving aid from the United States as well, often covertly. The aid-giving game became a battle of resources between the two super-powers, one

\footnotetext{
${ }^{68}$ Christian Parenti, Commentary, Afghanistan: The Use and Abuse of a Buffer State, 30 New POL. SCI., 1 (2008).

${ }^{69}$ See Peter Hopkirk, The Great Game: The Struggle For EMPIRE In CENTRAL Asia 2-10 (1992).

${ }^{70}$ See id.

71 "Khanates" are political entities ruled by a Khan.

72 See Parenti, supra note 68, at 97.
} 
in which the Soviets vastly out-spent the Americans. ${ }^{73}$ The situation resulted in some unusual building projects, such as the Kabul airport, built by the Russians but outfitted with U.S. communications equipment, and many Afghan roads, which were built mostly by U.S.-U.S.S.R. jointly funded projects. ${ }^{74}$ By the time the Soviets invaded Afghanistan in 1979, the United States was said to be heavily aiding the mujahideen. The Soviets were finally defeated after roughly a 10-year war, and Afghanistan completed yet another period of as a buffer state between warring nations.

\section{The Clan System}

Afghanistan's role as a buffer state undoubtedly contributed to its weak central government and reliance on local clans for support. ${ }^{75}$ After years of foreign invaders arbitrarily drawing territorial boundaries for the clans, Afghanistan has largely remained without strong central governance or national unity. ${ }^{76}$ Government bureaucracies, in turn, have not been able to provide basic services for survival, which has only strengthened clan unity over time. ${ }^{77}$ Having withstood various Afghan rulers and foreign invaders, the Afghan clan system has become strong, though not without sacrificing national loyalties and peace.

Afghanistan clans are well organized and operate as informal organizations sharing common goals, behaviors, and expectations, somewhat similar to a business enterprise. ${ }^{78} \mathrm{Clans}$ are organized mostly based on kin, which is inclusive of lineage by matrimony, but also includes

\footnotetext{
${ }^{73}$ See id.

${ }^{74}$ See id.

${ }^{75}$ See Jonathon Zartman, Stability Requires Ideas from the Past 5 (Feb. 15, 2009) (unpublished manuscript) (http://www.allacademic.com/meta/p313893_index.html).

${ }^{76}$ See Amitai Etzioni, Bottom-up Nation Building, POL'Y REV., Dec.-Jan 2010 at 51, 53.

${ }^{77}$ See Alessandra Ceccarelli, Clans, Politics, and Organized Crime in Central Asia, 10 TrENDS IN Organized CRIME 19, 23 (2007).

${ }^{78}$ See id. at 22.
} 
strong friendships. ${ }^{79}$ Interaction between clans is often governed by informal agreements, which establish norms and practices and act to preserve certain rights for various clans. Though not formalized, the agreements are respected, as they protect rights and privileges which clans believe may not be protected by the State Constitution or other regulations. ${ }^{80}$

Group loyalty is a key feature of clan culture, and can often direct how resources are allocated in Afghan society. ${ }^{81}$ These patron-client relationships enforce the clan structure by keeping loyalties within the local community. One member of a clan does favors for another in the clan (usually for someone in authority), in exchange for help in navigating some aspect of the local system. This system strengthens bonds within the clan, but does little to strengthen national unity. Patron-client relationships are often seen when a skilled clan member becomes involved in State politics. Members of the clan will expect State resources to be exploited, and jobs to be made available, for the benefit of the clan. ${ }^{82}$ Essentially, the clan becomes the predominant provider for the community, and the State merely operates as a conduit through which the most powerful clan members compete for assets.

Patron-client relationships also operate in Afghanistan's opium trade. Broadly speaking, the opium trade includes at least three groups which facilitate the export of opium: drug mafias, transnational criminal organizations, and terrorist groups. ${ }^{83}$ Transnational criminal organizations are mostly responsible for moving opium in and out of the region, while drug mafias are the link between the international trafficker and the local producer. Clans have close ties to both groups, as they typically control the local territory. The Taliban itself is a clan that greatly benefits from

\footnotetext{
79 See id. at 23.

${ }^{80}$ See id.

${ }^{81}$ See, e.g., Zartman, supra note 75 , at 5.

${ }^{82}$ See Ceccarelli, supra note 77, at 23.

${ }^{83}$ See id. at 30.
} 
the patron-client model if the drug trade. Afghanistan produces $92 \%$ of the world's opium. ${ }^{84}$ This is an incredible undertaking given the country's sparse resources, which provide little by way of financial, transportation, and other critical infrastructure. ${ }^{85}$ The Taliban, of course, do not grow and produce the opium, but rather are partners with the international traffickers, mafias, and local clans. They may provide protection, transportation, or a number of other services, depending on the circumstances. ${ }^{86}$ In return, the Taliban generates immense revenue, which flows back to their clan, who then purchase weapons, vehicles, phones, houses, and sponsor Madrassas to Pakistan to recruit new members. ${ }^{87}$ The patron-client relationship fuels the insurgency, which is why the United States and its coalition partners have allocated so many resources to the seemingly impossible task of cutting the financial "arteries" that flow from the opium trade to the Taliban. ${ }^{88}$ It is imperative that the United States recognizes that it is the financial resources that can be cut, and not the relationships that have existed and persevered in the country for centuries.

\section{Acknowledging Socio-Economic Problems}

An argument can be made that countries such as Afghanistan, with its unique history as a buffer state and dominant clan governance, are ripe targets for corruption. When viewed light of the collective action paradigm, it is perhaps easy to see how clans will act corruptly, given their expectations that every clan will act for its own benefit to compete for resources that have for

\footnotetext{
${ }^{84}$ Farhana Schmidt, From Islamic Warriors to Drug Lords: The Evolution of the Taliban Insurgency, 21 MEDITERRANEAN QUARTERLY 61, 63 (2010).

${ }^{85}$ See id.

${ }^{86}$ See Ceccarelli, supra note 77, at 30.

${ }^{87}$ See Schmidt, supra note 84, at 63.

${ }^{88}$ See id.
} 
decades been scavenged. However, given the extent to which the collection action problem exists, it is difficult to isolate whether it is the country's history and clans alone that have contributed to the problem. After all, Afghanistan is not the only focus of media attention regarding corrupt contingency procurements. ${ }^{89}$ These factors, however, help explain why principle-agent model solutions, such as the building-up of traditional anti-corruption institutions, seem to be less effective in Afghanistan than in countries without these characteristics.

It is important to note that the two models through which corruption at the highest and lowest levels of Afghan society has been viewed, the principal-agent model and collective action theory, are not mutually exclusive. Rather, they apply differently depending on the particular corruption problem at hand. Where much of the scholarly research has focused on analyzing corruption from either a collective action or a principal-agent perspective, both models must be considered, with particular emphasis on resolving the collective action problem, before tailoring strategies to a specific country. The success of the two investigative task forces that have managed, under extreme circumstances, to prepare cases against many allegedly corrupt officials in President Karzai's cabinet, suggests that those team members have broken from the expectation that all actors in their environment will behave corruptly. Perhaps it is the strong backing of the U.S. Government, which may limit the members' fear of reprisal, that has led to

\footnotetext{
${ }^{89}$ Two American-based companies, Red Star and Mina, were accused of circumventing government procurement regulations in a deal to provide jet fuel to Manas Air Base, Kyrgyzstan. Red Star was alleged to have signed a memorandum of agreement with Manas Air Base to deliver jet fuel for the KC-135 Stratotankers on the base. The agreement bypassed the Competition in Contracting Act (CICA), according to one university law professor. Another company, known as Mina, was awarded a sole-source contract under the national security exception to CICA. Both deals were viewed as suspect by the American media. See Aram Roston, Fueling the Afghan War: A Tale of Two Companies and a "Bribe" from the US in Kyrgyzstan, THE NATION, May 10, 2010, at 13, 15.
} 
their success. Any potential solution, it seems, must consider what variety of mechanisms or factors will change the traditional expectations that clans have held to this point.

Resolving the collection action problem is a grand task, one which contemplates changing the way in which people think. Three leading strategists have suggested alleviating the collective action problem by shifting societal norms from clan ideologies to objectively shared principles. ${ }^{90}$ One model describes this as a shift to a "universalistic" rather than a "particularistic" society, challenging Afghans' descriptive and normative beliefs that clans determine institutional norms. ${ }^{91}$ Another strategy suggests moving from "limited access orders" to "open access orders," or a shift from personal to impersonal power. ${ }^{92}$ The third model discusses the significance of partiality and impartiality in the exercise of government power, explaining that governmental officials should make decisions based on law and policy rather than case-by-case determinations. ${ }^{93}$ These strategies obviously share the theme that clans or communities must yield to an impartial and objective national identity based on law rather than individualized community needs. Recognizing the above principals as a means to overcoming the collective action problem, however, does not resolve the problem of implementation. Nationalism, even in the United States, was not a foregone conclusion during the early formation of the Union.

\section{Conclusion}

\footnotetext{
${ }^{90}$ See Persson, Rothstein, \& Teorell, supra note 50, at 20.

${ }^{91}$ See Alina Mungiu-Pippidi, Corruption: Diagnosis and Treatment, 17 J. DEMOCRACY 86, 87-88 (2006).

92 See Douglas C. NORTh, ET AL., Violence AND Social Orders: A CONCEPTUAL FrameWORK FOR INTERPRETING RECORDED HUMAN HISTORY (2009).

93 See Bo Rothstein \& Jan Teorell, What Is Quality of Government? A Theory of Impartial Government Institutions. 21 Governance 165, 174 (2008).
} 
The United Nations Office on Drugs and Crime has made a number of anti-corruption recommendations for post-war countries such as Afghanistan. The Obama Administration has tried to implement some of these recommendations, including the funding and backing of the investigative task forces that have been discussed. Other UNODC recommendations include the use of polygraphs for public officials or for certain employment with the government, the taking of integrity oaths, and hiring requirements which exclude anyone with a record of collusion. Full transparency and tight regulation of financial institutions, including the disclosure of assets, income, or other financial holdings, has been suggested. Encouraging legislatures to pass strict laws that would criminalize bribery, embezzlement, money laundering, abuse of power, and obstruction of justice, is recommended. Finally, cooperation with international institutions, such as the World Bank, has been suggested as a means of increasing accountability and transparency within the global marketplace. ${ }^{94}$ These "strong-arm" recommendations have been lauded by the international anti-corruption community, and hopefully will have a place in Afghan society in the future.

However, the problem with the implementation of these tactics is that they are a dramatic departure from the status quo, and do not take into consideration some of the very unique issues that have been discussed. Further, it is not clear whether these devices would take hold or garner support by local clans. Indeed, a more moderate would do less to upset the socio-economic underpinnings of the country. Such a moderate approach would involve analyzing the corruption problem through the paradigms that have been discussed, tailoring the corruption strategies to fit Afghanistan's unique characteristics, and preparing the "soil" for more robust mechanisms to take root sometime in the future.

\footnotetext{
${ }^{94}$ U.N. Office on Drugs and Crime, supra note 14, at 1.
} 
What will happen to the pending corruption cases in Afghanistan? This author believes that probably very little will be done at this time. It is clear that corruption problems exist in both the upper and lower echelons of Afghan society, and will continue to exist until the U.Sbacked anti-corruption teams are accepted by the Afghan government. The strengthening of key institutions continues to be the recommended model. As has been shown in the United States, the integration and overlapping of these institutions offers a tremendously effective means of combating corruption. These mechanisms, however, have been shown not to be effective in a number of countries in south-central Asia. Afghanistan's unique history and clan structure may provide some rationale for these failures. Two socio-economic models, the principal-agent model and collective action theory, offer perspectives as to how Afghanistan's history and clan structure might be inhibiting the implementation of traditional anti-corruption tools. A strong clan history that loathes outsiders and rewards clan loyalties will not yield to strong U.S. anticorruption mechanisms. The Afghan drug trade offers a glimpse into the patron-client relationships that clans rely on, and demonstrates how the Taliban provide a network of resources to assist the drug mafias and transnational criminal organizations. A strong-arm approach to corruption, like that embraced by the Obama administration, will probably not succeed for a number of years. Before these regulatory mechanisms can work, the clans must be convinced of the credibility of these mechanisms. 